\title{
EFEKTIVITAS KONSELING KELOMPOK DENGAN TEKNIK SELF MANAGEMENT UNTUK MENGURANGI PERILAKU PROKRASTINASI AKADEMIK SISWA DI SMA NEGERI 3 TARAKAN
}

\author{
Yospina, Hendra Pribadi \\ Fakultas Keguruan dan Ilmu Pendidikan, Universitas Borneo Tarakan \\ yrayday@gmail.com
}

\begin{abstract}
The formulation of the problem in this study is whether group counseling with self management techniques is effective to reduce students' academic procrastination behavior at Tarakan 3 public high school. This study aims to determine how effective group counseling with self management techniques is to reduce students' academic procrastination behavior at Tarakan 3 public high school.

This type of research is a quantitative approach that is experiment. This study uses an untreated control group design with dependent pretest and posttest design. The population in this study is 143 class XI students at SMA Tarakan and a sample of 20 class XI students in SMA Tarakan. Data collection methods in this study use the scale of academic procrastination with likert scale. Data analysis techniques in this study are descriptive statistical techniques and test hypotheses using MIXED ANAVA assisted by SPSS 24.0 for windows program.

Based on the results of the study before and after the treatment, obtained the results of calculation of hypothesis testing by looking at the table subject effect obtained $F$ value $=157.370$ and $p$ value $=0,00(p<0,05)$ and in the table pairwise comparisons shows that in the experimental group is significant $(M D=-19.600 ; p<0,05)$ and in the control group showed that is was not significant $(M D=-2.400 ; p>0,05)$. Based on the results of mixed anova (anava mixed design) test management using SPSS 24.00 for windows it can be coucluded that group counseling with self management techniques can reduce students' academic procrastination behavior at Tarakan 3 public high school.
\end{abstract}

Keyword: group counseling, self management, academic procrastination

\section{PENDAHULUAN}

Belajar adalah kegiatan yang berproses dan merupakan unsur yang sangat fundamental dalam penyelenggaraan setiap jenis dan jenjang pendidikan. Berhasil atau gagalnya pencapaian tujuan pendidikan bergantung pada proses belajar yang dialami siswa baik ketika dia berada di sekolah maupun di lingkungan rumah atau keluarganya sendiri (Syah, 2015). Asmani (2009) mengemukakan bahwa tujuan belajar adalah tidak lain mencari ilmu, dalam belajar sangat penting untuk meluruskan niat dan memfokuskan diri dalam belajar. Permasalahan yang dihadapi oleh para siswa disekolah seringkali tidak dapat dihindari. Hal tersebut juga disebabkan karena sumber-sumber permasalahan siswa banyak yang disebabkan oleh hal-hal diluar sekolah. Setiap siswa memiliki

latar belakang yang berbeda, hal ini tentunya memungkinkan siswa membawa berbagai permasalahan, seperti masalah pribadi, sosial, belajar, keluarga, dan permasalahan lain yang menganggu kegiatan belajar siswa. Fenomena kesulitan belajar seorang siswa biasanya tampak jelas dari menurunnya kinerja akademik atau prestasi belajarnya. Kesulitan belajar juga dapat dibuktikan dengan munculnya kelainan perilaku siswa seperti kesukaan berteriakteriak didalam kelas, mengusik teman, berkelahi, dan sering tidak masuk sekolah (Syah, 2015). Permasalahan siswa tidak boleh dibiarkan begitu saja, termasuk perilaku siswa yang tidak dapat melakukan 
aktivitas belajar yang efektif dan tidak sesuai dengan apa yang dibutuhkan dan diharapkan.

Zaman modern ini, teknologi berkembang dengan sangat pesat. Perkembangan tersebut memiliki dampak positif dan negatif yang besar terhadap kehidupan manusia. Salah satu dampak negatif yang dimaksud adalah meningkatnya kecenderungan siswa menunda-nunda pekerjaan dengan melakukan kegiatan yang kurang bermanfaat diluar kegiatan akademik (Munawaroh dkk, 2017). Siswa yang sering melakukan penundaan terhadap tugas pekerjaan yang penting, seringkali mengalami keterlambatan, mempersiapkan waktu yang sangat berlebihan dan gagal menyelesaikan tugas sesuai batas waktu yang telah ditentukan. Fenomena tersebut ditunjukkan dengan kebiasaan siswa yang menghabiskan waktu berjam-jam

menonton televisi, mengakses jejaring sosial, bermain gameonline, dan mengakses situs-situs media sosial seperti Facebook, Instagram, Whatsapp, Line, Youtube sebelum mereka belajar. Siswa lebih senang melakukan kegiatan-kegiatan diluar akademik yang kurang bermanfaat dari pada mengerjakan tugas-tugas sekolah, mengulang pelajaran yang telah diberikan dan belajar untuk persiapan pelajaran hari esok.

Berdasarkan hasil penelitian yang dilaksanakan oleh Munawaroh, Alhadi, \& Saputra (2017) hasil penelitian menunjukkan bahwa $17,2 \%$ pelajar SMP Muhammadiyah 9 Yogyakarta memiliki prokrastinasi akademik tinggi, $77,1 \%$ sedang, dan $5,7 \%$ rendah. Kebiasaan penundaan terhadap kegiatan yang seharusnya dikerjakan tepat waktu seperti yang telah disebutkan diatas dikenal dengan prokrastinasi.

Menurut Millgram (Ghufron \& Risnawita, 2017) mengatakan bahwa perilaku prokrastinasi adalah perilaku spesifik yang meliputi (1) suatu perilaku yang melibatkan unsur penundaan, baik untuk memulai maupun untuk menyelesaikan suatu tugas atau aktivitas; (2) menghasilkan akibat-akibat lain yang lebih jauh, misalnya keterlambatan dalam menyelesaikan tugas maupun kegagalan dalam mengerjakan tugas; (3) melibatkan suatu tugas yang dipersepsikan oleh pelaku prokrastinasi sebagai suatu tugas yang penting untuk dikerjakan, misalnya tugas kantor, tugas sekolah, maupun tugas rumah tangga; (4) menghasilkan keadaan emosional yang tidak menyenangkan, misalnya perasaan cemas, perasaan bersalah, marah, panik, dan sebagainya.

Istilah prokrastinasi berasal dari bahasa Latin procratination dengan awalan "pro" yang berarti mendorong maju atau bergerak maju dan akhiran "crastinus" yang berarti keputusan hari esok. Jika digabungkan menjadi "menangguhkan" atau "menunda sampai hari berikutnya" (Ghufron \& Risnawita, 2017). Salah satu persamaan kata prokratinasi ialah "cunctation" yakni menangguhkan atau menunda pekerjaan untuk dikerjakan diwaktu yang lain. Prokratinasi akademik yang dialami remaja jika tidak diidentifikasi dan berusaha diatasi akan berdampak negatif bagi siswa. Prokrastinasi berakibat pada banyaknya waktu yang terbuang sia-sia, tugas-tugas menjadi terbengkalai dan bila diselesaikan hasilnya menjadi tidak maksimal Ferrari, 1991 (dalam Munawaroh, Alhadi, \& Saputra, 2017). Prokratinasi akdemik juga berdampak negatif terhadap kegiatan akademik siswa. Bentuk prokrastinasi akademik yang terjadi pada siswa diantaranya yaitu menunda waktu belajar, tidak mengerjakan PR dirumah hingga terlambat mengumpulkan tugas dari guru, hal ini dapat mempengaruhi prestasi belajar siswa. Siswa yang melakukan prokratinasi akademik memiliki kecenderungan mendapat nilai rendah pada setiap mata pelajaran dan nilai ujian akhir Steel, Brothen, \& Wambach, Tice \& Baumeister (dalam Munawaroh, Alhadi, \& Saputra, 2017).

Prokrastinasi yang dilakukan oleh siswa merupakan perilaku negatif dan tidak bisa dibiarkan secara terus-menerus. Apabila hal ini terus meningkat maka akan berpengaruh pada penurunan prestasi belajar siswa, tidak tercapainya perkembangan potensi dengan baik, sehingga bisa saja siswa tidak naik kelas. Dalam penelitian ini, layanan bimbingan dan konseling sangat dibutuhkan untuk mengurangi perilaku prokrastinasi akademik siswa. Salah satu teknik dalam bimbingan dan konseling adalah teknik self 
management. Dengan menggunakan konseling kelompok dengan teknik self management, diharapkan dapat mengurangi perilaku prokrastinasi akademik pada siswa.

Teknik self management ini merupakan salah satu bagian dari pendekatan behavioral. Pengelolaan diri (self management) adalah prosedur dimana individu mengatur perilakunya sendiri. Pada teknik ini individu terlibat pada beberapa atau keseluruhan komponen dasar yaitu: menentukan perilaku sasaran, memonitor perilaku tersebut, memilih prosedur yang akan diterapkan, melaksanakan prosedur tersebut, dan mengevaluasi evektivitas prosedur tersebut (Komalasari, Wahyuni, \& Karsih, 2016). Dalam pelaksanaan pengelolaan diri (self management) biasanya diikuti dengan pengaturan lingkungan untuk mempermudah terlaksananya pengelolaan diri. Pengaturan lingkungan yang dimaksudkan untuk menghilangkan faktor penyebab (antecedent) dan dukungan untuk perilaku yang akan dikurangi (Komalasari, Wahyuni, \& Karsih, 2016).

Prokrastinasi yang dilakukan oleh siswa yang mempunyai kecenderungan untuk menunda atau tidak segera memulai pekerjaan, ketika menghadapi suatu pekerjaan dan tugas. Tidak peduli apakah penundaan tersebut mempunyai alasan atau tidak (Ghufron \& Risnawita, 2017). Dengan layanan konseling kelompok dengan teknik self management diharapkan efektif untuk mengurangi perilaku prokrastinasi akademik siswa. Hal ini sesuai dengan hasil penelitian yang dilakukan oleh Meilindani (2017) pada siswa XI Nautika A SMK Pelayaran Hang Tuah Kediri, bahwa hasil penelitian dan analisis data yang telah dilakukan menggunakan uji paired sample t-test, menunjukkan teknik self management efektif untuk mengurangi prokrastinasi akademik siswa, selain itu penelitian yang dilakukan oleh Sholichatun (2013) pada siswa kelas VIII E SMP Negeri 1 Sukumoro Ngajuk terkait Self Management pada perilaku prokrastinasi siswa. Penelitian menggunakan jenis penelitian preexperimental dengan jenis one group pretest dan post-test design hasil analisis menunjukkan bahwa self management dapat mengurangi perilaku prokrastinasi akademik siswa kelas VIII E SMP Negeri 1 Sukumoro Ngajuk.

Berdasarkan penjelasan diatas, peneliti menemukan hal yang sama di SMA Negeri 3 Tarakan pada saat observasi. Hasil observasi awal di SMA Negeri 3 Tarakan pada tanggal 2 Februari 2018, bahwa ada sebagian siswa yang di hukum oleh guru mata pelajaran berdiri didepan tiang bendara atau dijemur, bahkan berlari keliling lapangan karena siswa tersebut tidak mengerjakan tugas akademik yang telah diberikan gurunya kurang lebih satu minggu pengumpulan tugas, tetapi tidak dikerjakan bahkan tidak dikumpulkan. Penanganan terkait masalah ini belum secara langsung ditangani oleh guru BK, dikarenakan masalah tersebut ditangani oleh guru mata pelajaran terlebih dahulu yang secara langsung mengetahui sikap dan tingkah laku siswa didalam kelas seperti apa pada saat proses pembelajaran berlangsung, tanggung jawab siswa terhadap tugas akademik yang diberikan, serta hasil belajar atau nilai akademik siswa selama mengikuti pelajaran dikelas dan ketika diberikan tugas.

Selain observasi, peneliti juga melakukan wawancara dengan guru bimbingan dan konseling serta salah satu wali kelas di SMA Negeri 3 Tarakan. Menurut guru bimbingan dan konseling bahwa, ada sebagian siswa tidak menyelesaikan tugas dengan waktu yang telah ditetapkan, tidak bersungguhsungguh dalam mengerjakan tugas, bahkan tidak memperhatikan materi pelajaran yang telah berlangsung dalam proses pembelajaran dan menurut salah satu wali kelas, ada beberapa siswa melakukan penundaan terhadap tugas akademik yang telah diberikan, bahkan tidak mengerjakan tugas yang telah diberikan oleh beliau, hal ini dibuktikan dengan daftar nilai akademik siswa dikelas yang tidak memperoleh nilai di karenakan tidak mengumpulkan tugas.

Berdasarkan uraian latar belakang diatas maka penulis tertarik meneliti dan mengangkat judul "Efektivitas Konseling Kelompok Dengan Teknik Self Management Untuk Mengurangi Perilaku Prokrastinasi Akademik Siswa di SMA Negeri 3 Tarakan”. 


\section{METODE PENELITIAN}

Metode penelitian yang digunakan untuk mencari pengaruh perlakuan tertentu terhadap yang lain dalam kondisi yang terkendalikan, dengan memberikan perlakuan lalu diukur akibat dari perlakuan tersebut.Penelitian eksperimen dilakukan untuk membuktikan suatu hipotesis (Sugiyono, 2015).

Populasi dan Sampel Penelitian

Adapun untuk keperluan penelitian ini, yang menjadi populasinya adalah siswa kelas XI SMA Negeri 3 Tarakan yang berjumlah 143 siswa.

\section{Teknik Analisis Data}

Teknik pengumpulan data yang digunakan dalam penelitian ini adalah skala. Data dianalisis dengan menggunakan analisis deskriptif dan inferensial.

\section{HASIL PENELITIAN DAN PEMBAHASAN}

Berdasarkan hasil analisis terhadap penelitian yang dilakukan terhadap 10 siswa pada kelompok eksperimen dan 10 siswa pada kelompok kontrol sebagai subjek penelitian, dapat dikatakan bahwa terdapat keterkaitan antara teori dan kenyataan yang terjadi pada saat

dilaksanakannya penelitian.

Pelaksanaan penelitian terhadap kelompok ekperimen dengan memberikan perlakuan atau treatment berupa layanan konseling kelompok dengan teknik self management yang diberikan kepada sampel kelompok eksperimen yang berjumlah 10 siswa. Perlakuan dilaksanakan sebanyak 4 (empat) kali pertemuan, dengan alokasi waktu setiap kali pertemuan adalah $1 \mathrm{x} 45$ menit.

Sebelum memberikan perlakuan atau treatment kepada sampel, terlebih dahulu diberikan pre-test. Setelah selesai diberikan perlakuan atau treatment, maka selanjutnya diberikan post-test. Berdasarkan uji pairwise comparisons didapatkan bahwa kelompok eksperimen yang diberikan perlakuan dengan teknik self management mengalami perubahan prokrastinasi siswa. Hal ini menunjukkan bahwa perubahan prokrastinasi pada kelompok eksperimen adalah signifikan (MD=-19.600; $\mathrm{p}>0,05)$ yaitu 0.00 sedangkan pada kelompok kontrol tidak mengalami perubahan prokrastinasi siswa. Hal ini menunjukkan bahwa perubahan prokrastinasi pada kelompok kontrol adalah tidak signifikan ( $\mathrm{MD}=2.400$; $\mathrm{p}<0,05)$ yaitu 0.69. Peningkatan tidak signifikan yang ditunjukkan pada kelompok kontrol dengan nilai sig. $\mathrm{P}>0.05$ yaitu 0.69 , tidak menjadi masalah pada kolompok kontrol mengalami kenaikan asalkan tidak signifikan. Artinya terdapat perbedaan keefektifan antara kelompok eksperimen dan kelompok kontrol berdasarkan hasil uji pairwise comparisons yang menyatakan bahwa kelompok eksperimen yang diberi perlakuan dengan teknik self management mengalami perubahan dibandingkan dengan kelompok kontrol yang tidak diberi perlakuan.

Berdasarkan hasil observasi dan wawancara di SMA Negeri 3 Tarakan, pada kelompok kontrol yang mengalami peningkatan perilaku prokrastinasi disebabkan karena tidak adanya jam pelajaran BK pada siswa kelas XI dan siswasiswi di SMA Negeri 3 Tarakan diperbolehkan membawa $\mathrm{Hp}$ kesekolah. Itulah faktor luar yang menyebabkan tingkat perilaku prokrastinasi akademik siswa pada kelompok kontrol kelas XI IIS di SMA Negeri 3 Tarakan mengalami peningkatan.

Setelah uji pairwise comparisons maka dilakukan uji hipotesis data setelah perlakuan untuk mengetahui perbedaan efektivitas dari kedua kelompok eksperimen dan kelompok kontrol. Uji hipotesis ini menggunakan uji statistik mixed anava dengan uji test of within - subject effect. Berdasarkan uji test of within - subject effect, diketahui nilai $\mathrm{F}=157.370$ dan nilai $\mathrm{p}$ $=0,00(\mathrm{p}<0,05)$ terdapat interaksi antara waktu pengukuran (pre-test dan post-test) dan group (eksperimen dan kontrol). Interaksi tersebut menunjukkan bahwa perubahan skor yang berbeda secara signifikan dari pre-test dan pos-test antar kedua kelompok. Kelompok kontrol tidak mengalami penurunan skor dan kelompok eksperimen mendapatkan penurunan skor.

Selanjutnya kontribusi konseling kelompok dengan teknik self management untuk mengurangi perilaku prokrastinasi akademik siswa. Hasil analisis statistik multivariate tests. Data yang digunakan 
adalah nilai post-test pada kelompok eksperimen dan kelompok kontrol. Berdasarkan uji multivariate tests didapatkan bahwa rata-rata prokrastinasi siswa yang diberikan teknik pada kelompok eksperimen sebesar 0.933 artinya yang diberikan mengalami penurunan prokrastinasi siswa sebesar 93,3\%.

Menurut Snyder (dalam Praseipida, 2015) self monitoring melibatkan usaha individu untuk enampilkan dirinya didepan orang lain dengan cara memodifikasi penampilan dan memperhatikan informasi mengenai perbandingan sosial disekitarnya. pada tahapan stimulus control siswa dapat merencanakan perubahan perilaku agar prokratinasi akademik dialami siswa dapat berkurang. Menurut Sukadji (dalam Komalasari, Wahyuni, \& Karsih, 2016) stimulus control konseli membandingkan hasil catatan tingkah laku dengan target tingkah laku yang telah dibuat oleh konseli. Perbandingan ini bertujuan untuk mengevaluasi evektivitas dan efisiensi program Pada tahap evaluasi siswa dapat membandingkan atara perilaku sebelum dan setelah diberikan perlakuan. Setelah semua tahap terlewati, ada tahap self reward yang berfungsi untuk memperkuat perilaku baru. Menurut Thoresen dan Mahoney (dalam Nursalim, 2014) selfreward digunakan untuk memperkuat atau untuk meningkatkan respons yang diharapkan. Self-reward berfungsi mempercepat terget tingkah laku.

Berdasarkan kategorisasi prokrastinasi siswa pada kelompok eksperimen sebelum diberikan treatment yaitu SE, MI, HA, AD, JO, AI, IR, JU, JD, VI semua berada pada kategorisasi tinggi. Dan setelah diberikan treatment terjadi penurunan menjadi kategorisasi sedang dan rendah. Sedangkan pada kelompok kontrol tidak diberikan perlakuan atau treatment yaitu YU, AN, RO, PA, MI, HE, ME, IN, AP, AR semuanya juga berada pada kategorisasi tinggi. Setelah diberikan posttest masih berada pada kategorisasi tinggi.

$$
\text { Perilaku prokrastinasi siswa }
$$

merupakan perilaku yang dapat menimbulkan banyak dampak entah bagi diri individu itu sendiri maupun pihak lain sehingga perlu ditangani dengan pemberian treatment untuk mengurangi perilaku prokrastinasi akademik tersebut. Treatment yang digunakan dalam penelitian ini yaitu teknik self management untuk mengurangi perilaku prokrastinasi akademik siswa. Self management adalah suatu proses dimana konseli dapat mengarahkan perubahan perilaku dan dapat mengatur perilakunya sendiri.

Dalam penelitian ini teknik selfmanagement dikatakan efektif digunakan untuk mengurangi perilaku prokrastinasi akademik siswa. Hasil penelitian ini sejalan dengan hasil penelitian yang dilakukan oleh Scholichatun, Farida, Muhari (2013) berjudul penerapan strategi self management untuk mengurangi perilaku prokrastinasi akademik pada siswa kelas VIII E SMP Negeri 1 Sukomoro Nganjuk Tahun Ajaran 2012/2013 yang menyatakan bahwa teknik self management dapat mengurangi perilaku prokrastinasi akademik siswa kelas VIII E SMP Negeri 1 Sukomoro Nganjuk.

Perbedaan penelitian dengan Scholichatun, Farida, Muhari (2013) bahwa penelitian yang dilakukan pada siswa kelas VII E SMP Negeri 1 Sukumoro Ngajuk terkait self management pada perilaku prokrastinasi siswa. Penelitian menggunakan jenis penelitian preexperimental dengan jenis one group pretest dan post-test design hasil analisis menunjukkan bahwa self management dapat mengurangi perilaku prokrastinasi akademik siswa kelas VII E SMP Negeri 1 Sukumoro Ngajuk. Sedangkan penelitian saya yang berjudul evektivitas konseling kelompok dengan teknik self management untuk mengurangi perilaku prokrastinasi akademik siswa di SMA Negeri 3 Tarakan untuk melihat efektifvitas dari konseling kelompok dengan teknik self management menggunakan analisis data dengan uji anava campuran.

\section{KESIMPULAN}

Hasil penelitian mengenai efektivitas konseling kelompok dengan teknik self management untuk mengurangi perilaku prokrastinasi akademik siswa di SMA Negeri 3 Tarakan didapatkan hasil uji anava campuran yang dilakukan bahwa terdapat hasil skor pretest dan posttest prokrastinasi akademik siswa pada kelas 
eksperimen menurun setelah diberikan perlakuan / teknik self management.

Pada proses konseling kelompok dengan teknik self management menunjukkan nilai kontribusi 93,3\% yang artinya konseling kelompok dengan teknik self management efektif untuk mengurangi perilaku prokrastinasi akademik siswa di SMA Negeri 3 Tarakan.

Maka dapat disimpulkan bahwa konseling kelompok dengan teknik self management efektif untuk mengurangi perilaku prokrastinasi akademik siswa di SMA Negeri 3 Tarakan.

\section{DAFTAR PUSTAKA}

Arikunto, S. 2013. Prosedur Penelitian Suatu Pendekatan Praktik. Jakarta: Rineka Cipta

Asmani, J, M. 2009. Jurus-Jurus Belajar Efektif Untuk SMP dan SMA. Jogjakarta: Diva Press

Azwar, S. 2016. Penyususnan Skala Psikologi. Yogjakarta: Pustaka Belajar

Desmita. 2014. Psikologi Perkembangan Peserta Didik. Bandung: PT. Remaja Rosdakarya.

Ferrari J. R. Johnson, J.L., \& Mccown, W. G. (1995). Procrastination and task avoidance : theory, research, and treatment. New York \& London : Plenum Press.

Ghufron, M, N, \& Risnawita, R. 2017. Teori-Teori Psikologi. Jogjakarta: Ar-Ruzz Media

Komalasari, G, Wahyuni, \& Karsih. 2016. Teori dan Teknik Konseling. Jakarta: PT. Indeks

Kunarto, M, E. 2013. KonselingKelompok. Bandung: Alfabeta

Lubis, N, L. 2011. Memahami DasarDasar Konseling Dalam Teori dan Praktik. Jakarta: Kencana

Meilindani, G, S. 2018. Keefektifan teknik self management untuk mengurangi prokrastinasi akademik siswa kelas XI Nautika A SMK Pelayaran Hang Tuah Kediri Tahun Pelajaran 2017/2018. Pedagogia, 2(6): 3-9

Munawaro, M, L, Alhadi, S, \& Saputra, W, N, E. 2017. Tingkat
Prokrastinasi Akademik Siswa

Sekolah Menegah Pertama Muhammadiyah 9 Yogyakarta. Jurnal Kajian Bimbingan dan Konseling, 2(1): 26-31

Nurihsan, J, A. Bimbingan \& Konseling dalam Berbagai Latar

Kehidupan. Bandung: PT. Refika Aditama

Nursalim, M. 2014. Strategi \& Intervensi Konseling. Jakarta: PT. Indeks

Prayitno. 2012. Seri Paduan Layanan Dan Kegiatan Pendukung Konseling. Padang: Universitas Negeri Padang

Prayitno \& Amti, E. 2013. Dasar-Dasar Bimbingan dan Konseling. Jakarta: Rineka Cipta

Prayitno \& Amti, E. 2015. Dasar-Dasar Bimbingan dan Konseling. Jakarta: Rineka Cipta

Shadish, Cook, and Campbell. 2002. Experimental And Quasi Exsperimental Design For Generalized Causal Inference. USA: Houghton Mifflin Company

Sholichatun, N, Farida, \& Muhari. 2013. Penerapan Self Management Untuk Mengurangi Prokrastinasi Akademik Pada Siswa Kelas VII E SMP Negeri 1 Sukomoro

Ngajuk Tahun Ajaran 2012/2013. Jurnal BK UNESA, 1(2): 1

Sigit, S. 2003. Esensi Perilaku Organisasi. Yogjakarta: Lukman Offset

Simamora, R, H. 2008. Buku Ajar Kependidikan Dalam

Keperawatan. Jakarta: Buku Kedokteran EGC

Sugiyono. 2015. Metode Penelitian

Pendidikan Pendekatan

Kuantitatif, Kualitatif, dan $R \& D$. Bandung: Alfabeta

Sumantri, Syarif, M. 2015. Strategi Pembelajaran: Teori dan Praktik di Tingkat Sekolah Dasar. Depok: Rajagrafindo Persada.

Syah, M. 2015. Psikologi Belajar. Jakarta: PT. RajaGrafindo Persada

Warsiyah. 2015. Menyontek, Prokrastinasi \& Keimanan. Yogjakarta: Trussmedia Grafika 